\title{
PENGARUH PENGGUNAAN KARBON HITAM BERVARIASI TERHADAP SIFAT FISIKA SOL KARET SEPATU KANVAS UNTUK UMUM.
}

\author{
Oleh : Hadi Musthofa \& TC Bambang Supriyono
}

dalam rhadap

k sifat

sultant

Rubber,

temuan

1. 1992

Bogor,

(3)

(1)

\section{AIISTRACT}

The obyective of this researh is to know the in fluence carbon black to the physical properier nubber sol of canvas shoes for general. Vulkanized rubber makes fram rubber smoked thect as row material naphthenic oil, ZnO. stearic acid, carbon black. AoSP, MBT, MBTS, IMI and sulphur. Raw material rubber and ingredient were compounded in two roll mill ind formed to slab by hydroulic press at temperatur $150^{\prime \prime} \mathrm{C}$ and pressure $150 \mathrm{~kg} / \mathrm{cm}^{2}$ The wwitt of this researhiindi cated that unsignificant different of treatment

\section{INTISARI}

Mnelitian ini bertujuan untuk mengetahui pengaruh karbon hitam terhadap sifat fisika sol Airet sepatu kanvas untuk umum. Vulkanisat karet dibuat dari bahan baku Rubber smoked theet di tambah bahan-bahan berupa naphthemic oil, ZnO, Asam stearat karbon hitom. IOSP, MBT, MBTS, TMT dan sulfur: Bahan-bahan tersebut diatas di komponiding pado whiuah alat two roll. Kompon yang dihasilkan di buat menjadi beniuk lembaran dengan itensgunakan hidroulic press pada suhu $150^{\circ} \mathrm{C}$ dan tekanan $150 \mathrm{~kg} / \mathrm{cm}^{2}$. Hasil analisa thiisuk menunjukkan bahwa tidak adanya perbedaan perlakuan.

\section{PENDAHULUAN}

Produk yang dibuat dari karet pada saat ini bermacam-macam bentuk dan tegunaan, dan hal ini sesuai dengan kebutuhan hidup manusia.Secara garis besar moduk tersebut dibedakan menjadi dua macam yaitu produk karet untuk keperluan ieknis dan keperluan non teknis.

Salah satu diantara produk karet non teknik yang diperlukan oleh manusía berupa sol sepatu dan mutunya ditentukan oleh beberapa faktor. Antara lain suhu, iekanan, waktu vulkanisasi dan komposisi kormpon yang dipergunakan. Bahan baku yang dipergunakan dalam pembuatan sol sepatu dapat berasal dari karet alam, karet Hintestis atau merupakan campuran kedua bahab tersebut.(3)Untuk memdapatkan produk akhir yang kualitasnya baik, maka pada bahan baku perlu diberikan bahanhahan tambahan berupa bahan pelunak, pengatif, pencepat, anti oksidan, bahan jemvulkanisasi dan bahan pengisi. $(3,4)$

Dalam kompon karet bahan pengisi ditambahkan dalam jumlah besar. Bahan jeneisi dibagi atas dua golongan yaitu : golongan bahan pengisi tidak aktif dan gulongan bahan pengisi aktif atau penguat. (4) Bahan pengisi penguat akan 
menambah kekerasan, ketahanan sobek, ketahanan kikis dan tegangan putus yang tinggi pada barang karetnya. Penambahan bahan pengisi tidak aktif hanya akan m,enambah kekerasan dan kekakuan pada barang karetnya, sedangkan kekuatan dan sifat yang lainnya akan berkurang. Harganya lebih murah dari harga karet mentahnya atau harga bahan pengisi aktif, sehingga bahan pengisi tidakaktif terutama digunakan untuk memakan harga barang jadi karetnya.

Adapun yang termasuk golongan bahan pengisi tidak aktif adalah kaolin, berbagai jenis tanah liat, kalsium karbonat, magnesium karbonat, barium sulfat dan barit. Sedangkan yang termasuk bahan pengisi penguat meliputi karbon hitam, silika. Aluminium silikat dan magnesium silikat. Penguatan pada bahan pengisi ditentukan oleh ukuran, keadaan permukaan dan bentuk butiran halusnya. (3)

Dalam kompon karet sering digunakan campuran bahan pengsisi aktif dan bahan pengisi tidak aktif dengan memperhatikan. mudahnya waktu pengolahan dan sifat barang karet yang dikehendaki atau sesuai dengan tujuan penggunaannya.

Pemakaian karbon hitam ke dalam campuran kompon karet harus dalam jumlah yang tepat, hal ini disebabkan penambahan dalam jumlah banyak.

Maka produk akhir mempunyai kekerasan yang tinggi, sedangkan penambahan dalam jumlah kecil produk akhir yang dihasilkan mempunyai kekerasan yang rendah. Untuk mengetahui jumlah karbon hitam yang tepat dalam penambahan perlu diadakah penelitian, sehingga dapat memenuhi persyaratan SII. 1407-85 (1)

\section{MATERI DAN METODA}

\section{MATERI}

1.1 Bahan

Pada penelitian ini digunakan bahan berupa

RSS

AOSP

Naphtenicoil MBT

$\mathrm{ZnO}$

MBTS

Asam strearat TMT

Karbon hitam sulfur

1.2 Peralatan

Dalam penelitian ini peralatan yang dipergunakan terdiri : - Neraca analitik - shoretype hardness

- Two roll mill

- Hydroulic press

- Stop Watch

- Showbury curometer

- Tensile strength tester

Permanent strain Set

Abrassion tester

Ross Flexing

Microgauge

Gelas ukur
2. METODA

2.1 Rancangan

Komposisi kompon karet yang dipergunakan dalam penelitian seperti pada tabel 1. berikut.

Tabel 1 : Komposisi kompon karet sol karet

\begin{tabular}{|c|c|c|c|c|c|c|c|}
\hline \multirow[t]{2}{*}{ No. } & \multirow[t]{2}{*}{ Jenis Bahan } & \multicolumn{6}{|c|}{ Bagian berat } \\
\hline & & $\mathrm{I}$ & II & III & IV & $\mathrm{V}$ & VI \\
\hline 1. & RSS & 100 & 100 & 100 & 100 & 100 & 100 \\
\hline 2. & Naphtenic oil & 5 & 5 & 5 & 5 & 5 & 5 \\
\hline 1. & $\mathrm{ZnO}$ & 5 & 5 & 5 & 5 & 5 & 5 \\
\hline 4. & Asam stearat & 0,5 & 0,5 & 0,5 & 0,5 & 0,5 & 0.5 \\
\hline 5. & Karbon hitam & 30 & 35 & 40 & 45 & 50 & 55 \\
\hline 6. & AoSp & 1 & 1 & 1 & 1 & 1 & 1 \\
\hline 7. & MBT & 0,4 & 0,4 & 0,4 & 0,4 & 0,4 & 0,4 \\
\hline 8. & MBTS & 0,4 & 0,4 & 0,4 & 0,4 & 0,4 & 0,4 \\
\hline 9. & TMT & 0,2 & 0,2 & 0,2 & 0,2 & 0,2 & 0,2 \\
\hline 10. & Sulfur & 2 & 2 & 2 & 0,3 & 0,3 & 0,3 \\
\hline
\end{tabular}

2.2 Pembuatan Kompon

Timbang masing-masing bahan sesuai dengan keperluan.

Pencampuran dilakukan dengan menggunakan mesin Two roll mill

Mula-mula karet alam (RSS) digiling sampai plastis dengan homogen.

Selanjutnya berturut-turut tambahkan naphtenic oil, $\mathrm{ZnO}$, asam stearat, karbon hitam, Aosp. Pada tiap-tiap kali penambahan lakukan sampai merata. Selanjutnya secara bertahap tambahkan MBT, MBTS, TMT dan Sulfur.

Temperatur selama penggilingan dijaga jangan sampai melebihi dari $60^{\circ} \mathrm{C}$. Sebelum di vulkanisasi kompon dikondisikan selama 24 jam

2.1 Pembuatan slab

Sebelum dibuat lembaran (slab) dengan ukuran tertentu, terlebih dahulu kompon ditentukan waktu vulkanisasi yang optium pada suhu $150^{\circ} \mathrm{C}$ dengan alat curometer.

Pembuatan lembaran (Slab) dilakukan menggunakan alat Hydroulic press. Timbang kompon dengan berat tertentu sesuai dengan ketebalan dari contoh uji.

Masukkan kompon dalam frame dan lakukan vulkanisasi dengan alat hydroulic press pada suhu, tekanan dan waktu tertentu.

Ambil lembaran dari alat dan biarkan dalam ruang kondisi selama 24 jam. 
2.4 Pengujian

Kompon karet yang sudah divulkanisasi dalam bentuk lembaran dengan menggunakan alat hydroulic Press, selanjutnya dilakukan pengujian terhadap sifat-sifat fisikanya antara lain meliputi tegangan putus, perpanjangan putus, ketahanan sobek, perpanjangan tetap $50 \%$, bobot jenis, ketahanan kikis, ketahanan retak lentur dan kekerasan shore $\mathrm{A}$.

2.5 Analisa dan Pembahasan

Hasil penelitian pengaruh penambahan bahan pengisi berupa karbon hitam terhadap sifat fisika sol karet untuk sepatu kanvas keperluan umum dapat dilihat pada lampiran satu. Dari tabel tersebut diketahui ternyata penggunaan karbon hitam yang dicampurkan ke dalam kompon karet untuk sol dengan jumlah mulai 30 bagian sampai dengan 55 bagian. maka sifat fisika sol karet sepatu kanvas untuk umum dengan no. SII. 1407 - 84 secara keselutuhan dapat dipenuhi yaitu dengan penambahan bahan pengisi berupa karbon hitam sebanyak 50 bagian dan 55 bagian.

Adapun penggunaan bahan pengsisi berupa karbon hitam mulai dari 30 bagian sampai dengan 45 bagian, untuk sifat fisika yang lain dapat dipenuhi, sedangkan sifat fisika yang berupakekerasan tidak dapat dipenuhi, yaitu kekersan tertinggi dicapai dengan menggunakan bahan karbon hitam sebesar 45 bagian.

Berdasarkan data rata-rata hasil uji seperti yang terdapat pada lampiran dua ternyata setiap penambahan bahan pengisi berupa karbon hitan dapat memperbaiki sifat fisika produk akhir yang dihasilkan, adapun sifat fisika yang terbaik diperoleh dengan penambahan bahan pengisi karbon hitam sebesar 55 bagian ke dalam campuran kompon karet.

Pada penggunaan bahan pengisi penguat sebesar 35 bagian ke dalam campuran kompon karet, maka hasil uji sifat fisikanya menunjukkan terdapat beberapa kelemahan antara lain ketahan sobek, bobot jenis, perpanjangan tetap dan sifat fisika tersebut menunjukkan lebih rendah bila dibandingkan penambahan bahan pengisi berupa karbon hitam sebesar 30 bagian, 40 bagian, 45 bagian, 50 bagian dan 55 bagian. Adanya kelemahan ini kemungkinan disebabkan oleh adanya penyebaran dari bahan karbon ke dalam kompon karet yang kurang merata dan hal ini lebih jelas apabila dilihat dari bobot jenis untuk kompon karet dengan menggunakan bahan pengsisi sebesar 35 bagian, lebih rendah daripada penggunaan bahan pengisi yang lainnya.

Ketidak keseragaman dalam hal penyebaran bahan pengisi karbon hitam, ternyata tidak hanya berpengaruh terhadap bobot jenis, tetapi juga mempengaruhi hasil sifat fisika yang lain yaitu ketahanan kikis, seperti pada lampiran dua justru penggunaan bahan pengisi 45 bagian dan 50 bagian lebih baik daripada penggunaan bahan pengsisi karbon hitam ke dalam kompon karet sebesar 55 bagian.
Dari analisa statistik terhadap hail uji sifat sol karet sepatu kanvas untuk umum dengan menggunakan metode Completely Randomized design, ternyata diperoleh $\mathrm{F}$ hitung untuk uji tegangan putus, perpanjangan putus, kethanan sobek, perpanjangan tetap, bobot jenis, ketahanan kikis dan kekerasan lebih kecil $\mathrm{F}$ tabel baik yang $1 \%$ maupun $5 \%$, sehingga dengan demikian dapat dikatakan tidak menunjukkan adanya perbedaan perlakuan.

\section{KESIMPULAN}

1. Pada penambahan karbon hitam 30 bagian sampai 45 bagian semua sifat fisika memenuhi syarat, terkecuali pada kekerasan tidak memenuhi persyaratan.

2. Penambahan bahan karbon hitam pada kompon sebesar 50 bagian dan 55 bagian dapat memenuhi persyaratan pada sol karet sepatu kanvas.

3. Sifat fisika terbaik dihasilkan dengan menggunakan bahan karbon hitam 55 bagian.

4. Hasil analisa statistik tidak menunjukkan adanya perbedaan perlakuan.

\section{DAFTAR PUSTAKA}

1. Departemen Perindustrian "SII. No. 1407-86" Sepatu Kanvas Untuk Umum.

2. Departemen Perindustrian " SII. No. 0944-84 "Sol Karet Cetak"

3. GP Murya "Rubber Technology and Manufacture" ABP Delhi - 110007

4. BPP Bogor \& Rubber Stichting Annsterdam "Petunjuk Pembuatan Barang Dars Karet Alam" PT. KINTA. 


\begin{tabular}{|c|c|c|c|c|}
\hline \multirow{6}{*}{\multicolumn{2}{|c|}{ 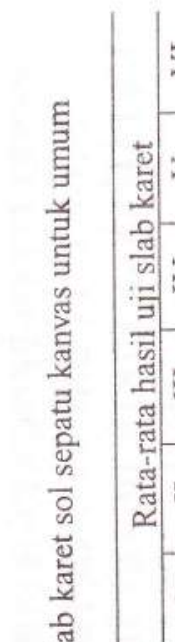 }} & 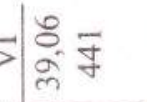 & 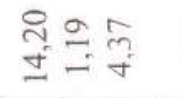 & In \\
\hline & & 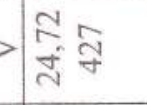 & ते & So요 \\
\hline & & 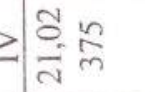 & 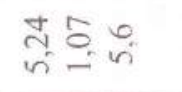 & 5o: \\
\hline & & $=\mid \begin{array}{ll}\hat{\sigma} & 0 \\
0 & 0 \\
0 & m\end{array}$ & $\begin{array}{l}\forall+50 \\
\forall-6\end{array}$ & 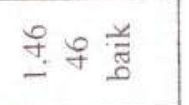 \\
\hline & & 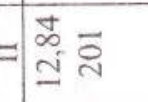 & $\begin{array}{l}\text { से } \hat{\sigma} n \\
\text { món }\end{array}$ & $\stackrel{\text { Iิ }}{y}$ \\
\hline & & $-a_{\sigma} \pm$ & $\begin{array}{l}50 \\
\sigma \\
\dot{\sigma}\end{array}$ & 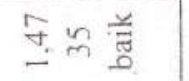 \\
\hline$\frac{3}{5}$ & 胥 & है है & 苂 & 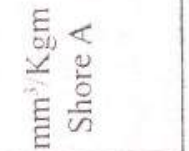 \\
\hline 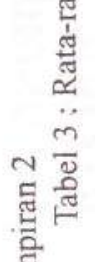 & 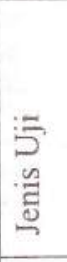 & 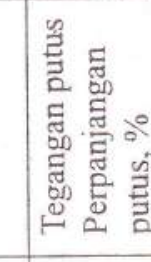 & 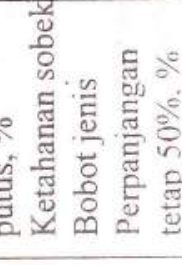 & 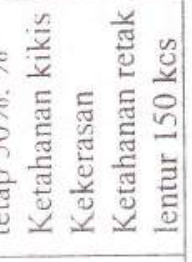 \\
\hline స్ & ż & -4 & $\dot{m}+\dot{r}$ & $\therefore r$ \\
\hline
\end{tabular}

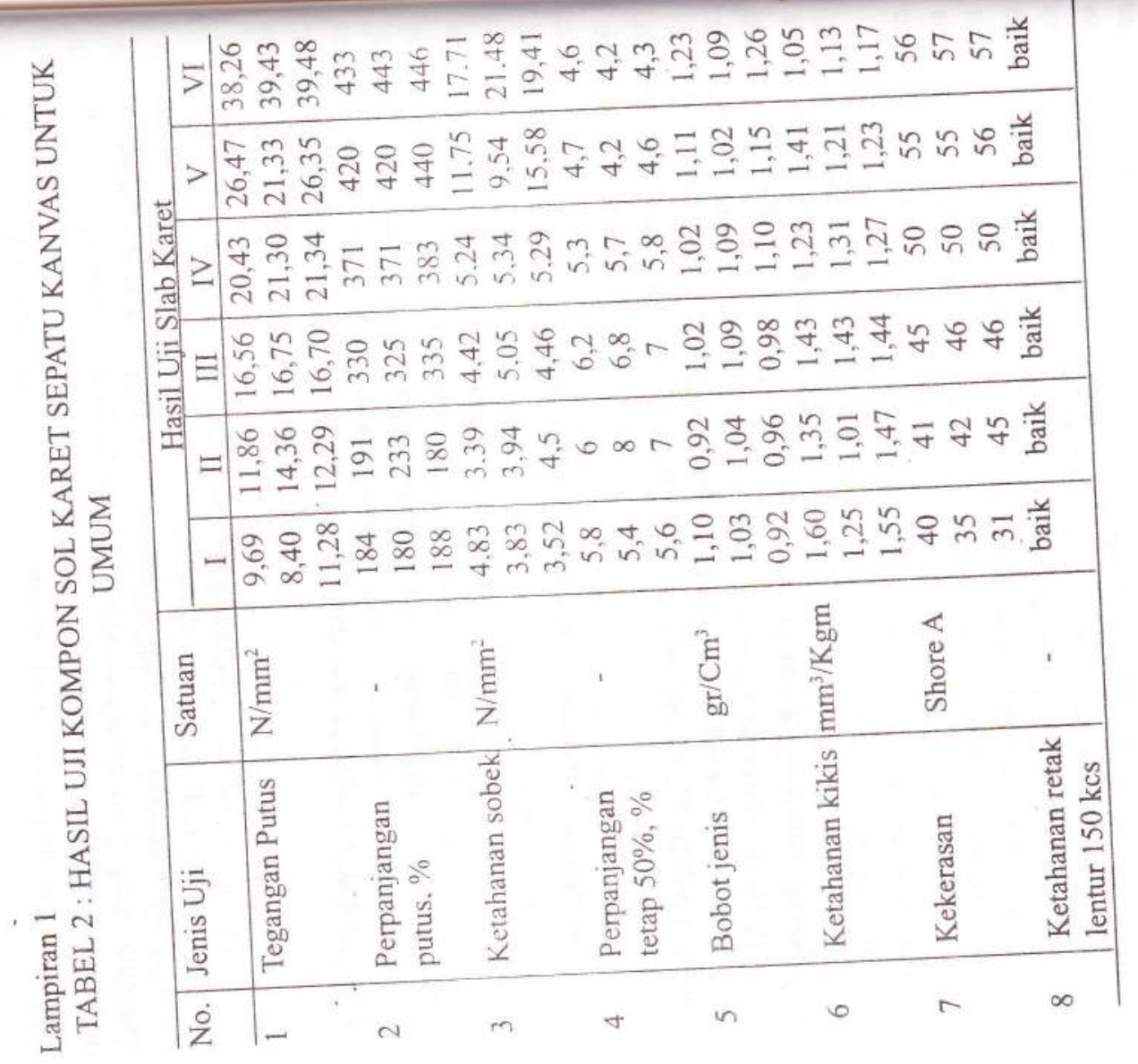

